\title{
Age- and sex-related changes in hematological parameters in healthy Malawians
}

\author{
Wilson L Mandala ${ }^{1-3}$ \\ Esther N Gondwe' \\ Jenny M MacLennan ${ }^{1,4}$ \\ Malcolm E Molyneux ${ }^{1,5}$ \\ Calman A MacLennan 1,6,7 \\ 'The Malaria Immunology Group, \\ Malawi-Liverpool Wellcome Trust \\ Clinical Research Programme, \\ College of Medicine, Blantyre, Malawi; \\ ${ }^{2}$ Biomedical Sciences Department, \\ College of Medicine, Blantyre, Malawi; \\ ${ }^{3}$ Biomedical Sciences Department, \\ Academy of Medical Sciences, Malawi \\ University of Science and Technology, \\ Thyolo, Malawi; ${ }^{4}$ Department of \\ Zoology, University of Oxford, \\ Oxford, UK; ${ }^{5}$ Department of Clinical \\ Sciences, Liverpool School of Tropical \\ Medicine, Liverpool, UK; ${ }^{6}$ The Jenner \\ Institute, Nuffield Department of \\ Medicine, University of Oxford, \\ Oxford, UK; ${ }^{7}$ Institute of Immunology \\ and Immunotherapy, College of \\ Medicine and Dental Sciences, \\ University of Birmingham, Birmingham, \\ UK
}

This article was published in the following Dove Press journal:

Journal of Blood Medicine

28 August 2017

Number of times this article has been viewed

Aim: The aim of the study was to determine how values for white blood cell (WBC) counts, hemoglobin $(\mathrm{Hb})$, hematocrit $(\mathrm{Hct})$, mean corpuscular volume $(\mathrm{mcv})$, and platelet counts vary with age and sex in healthy Malawians.

Methods: We recruited 660 (316 male and 344 female) participants in 12 different age groups. An ethylenediaminetetraacetic acid-anticoagulated blood sample collected from each participant was analyzed using a hematological analyzer.

Results: WBC counts decreased with age with the lowest counts observed in the 20 to $<60$ years old group. Median WBC counts for 20 to $<60$ year old females $\left(5.9 \times 10^{9} / \mathrm{L}\right)$ were significantly higher than those for men $\left(4.7 \times 10^{9} / \mathrm{L} ; p=0.015\right)$ of the same age. Hb and Hct increased between 5 and 10 years in males and 10 and 15 years in females to adult levels. Males aged 5 to $<10$ years had significantly higher $\mathrm{Hb}(13.05 \mathrm{~g} / \mathrm{dL})$ and $\mathrm{Hct}(42.50 \%)$ compared to females of the same age $(10.40 \mathrm{~g} / \mathrm{dL}$ and $32.55 \%$, respectively; $p<0.0001$ for both parameters). Platelet counts in males, which were highest between 3 and 5 years $\left(376 \times 10^{9} / \mathrm{L}\right)$, decreased to lowest counts among 5 to $<10$ year olds $\left(238 \times 10^{9} / \mathrm{L}\right)$, while in females these decreased from $402 \times 10^{9} / \mathrm{L}$ in 6 to $<10$ years olds to $226 \times 10^{9} / \mathrm{L}$ in 10 to $<15$ year olds. mcv median values were high in neonates reaching a nadir at $13-18$ months and then increased throughout life. Females aged 0 to $<6$ months had significantly higher mov values $(81.85 \mathrm{fL})$ than males of the same age (69.3 fL; $p<0.0001)$.

Conclusion: This study provides hematological values according to age and sex that are suitable for reference use in studies among Malawian subjects.

Keywords: hematological values, healthy Malawians, age, sex

\section{Introduction}

Just as the immune system develops and matures with age, ${ }^{1}$ various hematological parameters have also been shown to change and develop with age ${ }^{2}$ although other factors such as genetics, sex, altitude, and life style may affect this process. ${ }^{3}$ Most of these factors vary depending on the population and geographical area studied, ${ }^{4,5}$ suggesting that reference values that have been validated for one country or age group cannot be assumed for application in populations from other countries. ${ }^{3}$

Reference ranges are important for monitoring pathophysiological changes after infection or disease or following the administration of drugs in therapeutic or clinical interventions and vaccine studies. ${ }^{6}$ Since diseases such as malaria and HIV/AIDS affect hematological parameters in different ways, analysis of blood samples for full blood counts (FBCs) is therefore now routinely performed to check for variations which could be due to these diseases. ${ }^{7}$

Correspondence: Wilson L Mandala Malawi-Liverpool Wellcome Trust, PO Box 30096, Blantyre, Malawi

Tel +265995 450785

Fax +265 I 874700

Email wmandala2002@gmail.com 
Studies in African countries have reported differences in normal values from those reported in other continents. ${ }^{8-11}$ Studies previously conducted to establish hematological reference values for a Malawian population limited their participants to children aged $<1$ year ${ }^{12,13}$ and young adults aged between 19 and 30 years. ${ }^{14}$ We conducted this study to determine how white blood cells (WBC) counts, hemoglobin (Hb), hematocrit (Hct), mean corpuscular volume (mcv), and platelet counts vary with age and sex in Malawians from birth to adulthood.

\section{Materials and methods}

\section{Study area and recruitment of study participants}

Some findings concerning the study site and the population investigated in this paper have been published before. ${ }^{5,15}$ The study was conducted at the Ndirande Health Centre, Ndirande township, Blantyre, Malawi, between October and December 2005 and September and November 2006. Study participants were healthy volunteers from the township, were not HIV infected, had no known active disease, were not malnourished, not on treatment for any known infectious or noncommunicable disease, and were made aware of the study by health care assistants at immunization clinics and by local leaders in the community. Infants were recruited when they reported for routine vaccination, whereas adults were recruited from the community. Each study participant was assessed clinically by a trained research nurse and a clinical officer, both with $>5$ years experience in assessing and recruiting study participants into clinical research projects.

The clinical assessment process included a review of each participant's health passport, a booklet issued to every Malawian citizen from birth having medical records of all diagnoses and treatment given to that individual, and a clinical examination. With the aid of a brief questionnaire, participants were asked whether they were on any medication and whether they had a history of any illness. Participants were assessed for febrile illness, infections such as malaria, severe malnutrition, and clinical AIDS. Severe malnutrition was defined as weight-for-height $<70 \%$ in children or body mass index $<16 \%$ in adults. Only those participants found to be afebrile (axillary temperature $\leq 38^{\circ} \mathrm{C}$, not severely malnourished, not on any treatment, HIV uninfected, not infected with Plasmodium falciparum parasites, and without any active or past history of recurrent or chronic infections) were defined as healthy and recruited into the study. Approximately 50 subjects were recruited into each of the following 12 age groups: neonates (cord blood sample), 0 to $<6,6$ to $<12,12$ to $<18$, and 18 to $<24$ months, 2 to $<3$,
3 to $<5,5$ to $<10,10$ to $<15,15$ to $<20,20$ to $<60$, and $\geq 60$ years. After informed consent, baseline demographic data, height, and weight were recorded, and a 5-mL blood sample was obtained with $1 \mathrm{~mL}$ collected in an ethylenediaminetetraacetic acid (EDTA)-anticoagulated tube. Informed consent was obtained from each participant or a parent or a guardian of every child. Exclusion criteria were presence of active disease and/or fever $\left(>38^{\circ} \mathrm{C}\right.$ axilla $)$, receiving medication at the time of recruitment, and severe malnutrition (Figure 1). Blood samples were tested for HIV seropositivity and malaria parasitemia and the results of those participants found to be either HIV infected or parasitemic with $P$. falciparum were not included in the final data analysis. A follow-up appointment was offered 1 week later to give results to interested study participants. HIV-infected adults and children were referred to the antiretroviral therapy clinic.

\section{Investigations}

HIV testing was performed using two rapid test kits; Determine (Abbott Laboratories, Abbott Park, IL, USA) and Unigold (Trinity Biotech, Dublin, Ireland). Thick and thin blood smears were prepared by standard methodology. WBC, $\mathrm{Hb}$, Hct, mcv, and platelet counts were determined using an HMX Hematological Analyzer (Beckman Coulter, Brea, CA, USA) using the sample collected in the EDTA tube.

\section{Ethical approval}

Ethical approval for this study was obtained from College of Medicine Research and Ethics Committee in Blantyre, Malawi.

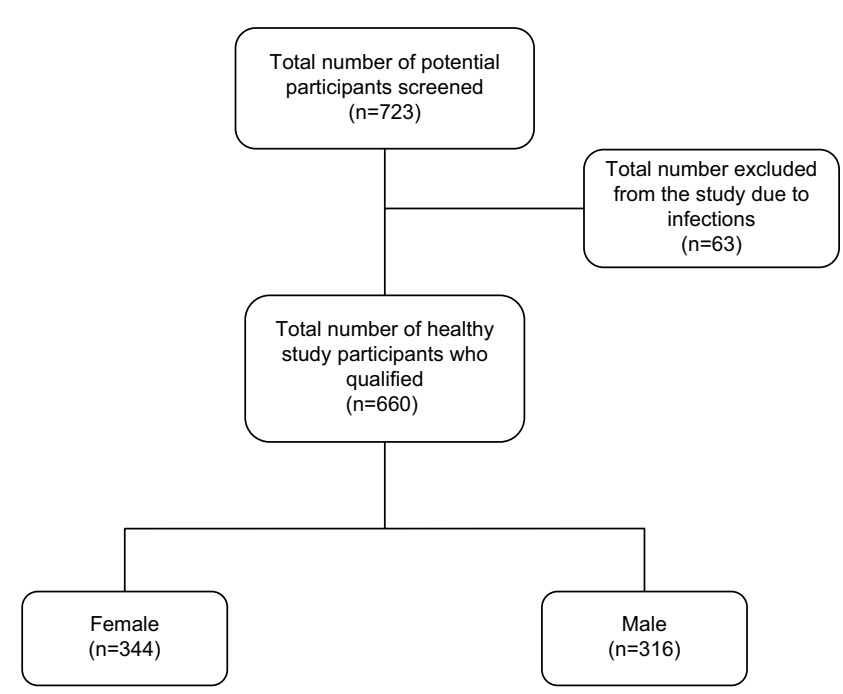

Figure I A schematic presentation depicting the number of total potential study participants screened, how many were excluded from the study due to various reasons, and how many female and male participants had their data used in the final statistical analysis. 


\section{Statistical analysis}

For statistical analysis, subjects were divided into 12 age groups as indicated in Table 1. Mann-Whitney test was used to determine the statistical significance of the observed differences between male and female participants of different age groups. Statistical tests were performed using GraphPad Prism version 6.01 for Windows (GraphPad Inc, La Jolla, CA, USA). The results in Table 2 are presented as median values (minimum and maximum range) of $\mathrm{WBC}, \mathrm{Hb}$, Hct, mcv, and platelet counts.

Table I Age distribution, sex, number and age (range) in months or years of the study participants whose data were used and reported on in the study

\begin{tabular}{|c|c|c|c|}
\hline \multirow[t]{2}{*}{ Age range } & \multicolumn{3}{|c|}{ Number of Study Participants and the medians and range of their ages } \\
\hline & Female & Male & Combined \\
\hline \multirow[t]{2}{*}{ Neonates (cord blood) } & 37 & 24 & 61 \\
\hline & - & - & - \\
\hline \multirow[t]{2}{*}{0 to $<6$ months } & 44 & 24 & 68 \\
\hline & $3(I-6)$ months & $2(I-6)$ months & $3(I-6)$ months \\
\hline \multirow[t]{2}{*}{6 to $<12$ months } & 31 & 35 & 66 \\
\hline & II (7-12) months & $10(7-12)$ months & $10.5(7-12)$ months \\
\hline \multirow[t]{2}{*}{12 to $<18$ months } & 15 & 27 & 42 \\
\hline & $15(13-18)$ months & $15(13-18)$ months & $15(13-18)$ months \\
\hline \multirow{2}{*}{18 to $<24$ months } & 16 & 33 & 49 \\
\hline & 21.5 (19-23) months & 22 (19-24) months & 22 (19-24) months \\
\hline \multirow[t]{2}{*}{2 to $<3$ years } & 20 & 28 & 48 \\
\hline & $2.4(2.1-3.0)$ years & $2.5(2.1-3.0)$ years & $2.4(2.1-3.0)$ years \\
\hline \multirow[t]{2}{*}{3 to $<5$ years } & 22 & 29 & 51 \\
\hline & $4.0(3 . I-5.0)$ years & $4.4(3.2-5.0)$ years & $4.2(3.1-5.0)$ years \\
\hline \multirow[t]{2}{*}{5 to $<10$ years } & 30 & 26 & 56 \\
\hline & $7.1(5.1-10.0)$ years & $6.8(5.3-10.0)$ years & $7.0(5.1-10.0)$ years \\
\hline \multirow[t]{2}{*}{10 to $<15$ years } & 36 & 17 & 53 \\
\hline & $12.2(10.1-14.9)$ years & $11.2(10.1-14.9)$ years & II.8 (10.1-14.9) years \\
\hline \multirow[t]{2}{*}{15 to $<20$ years } & 29 & 29 & 58 \\
\hline & $18.0(15.4-19.8)$ years & $16.8(15.4-20.0)$ years & $17.2(15.4-20.0)$ \\
\hline \multirow[t]{2}{*}{20 to $<60$ years } & 33 & 20 & 53 \\
\hline & $23.9(20.3-57.4)$ & $22.0(20.7-37.1)$ years & $23.8(20.3-57.4)$ \\
\hline \multirow[t]{2}{*}{$\geq 60$ years } & 31 & 24 & 55 \\
\hline & $65.0(60.0-81.0)$ years & $70.5(60.0-92.0)$ & $66.0(60.0-92.0)$ years \\
\hline Total Numbers & 344 & 316 & 660 \\
\hline
\end{tabular}

Table 2 Medians (minimum and maximum range) for WBC counts, Hb concentration, Hct percentage, mcv, and platelet counts for the study participants of different age and sex

\begin{tabular}{|c|c|c|c|c|c|c|c|c|c|c|}
\hline Age group & $\begin{array}{l}\text { WBC } \\
\left(10^{\%} / L\right)\end{array}$ & $\begin{array}{l}\text { p-value } \\
\text { (M vs F) }\end{array}$ & $\mathrm{Hb}(\mathrm{g} / \mathrm{dL})$ & $\begin{array}{l}\text { p-value } \\
\text { (M vs F) }\end{array}$ & Hct (\%) & $\begin{array}{l}\text { p-value } \\
\text { (M vs F) }\end{array}$ & $\begin{array}{l}\text { MCV } \\
\text { (fL) }\end{array}$ & $\begin{array}{l}\text { p-value } \\
\text { (M vs F) }\end{array}$ & $\begin{array}{l}\text { Platelet } \\
\text { Count }\left(10^{9} / \mathrm{L}\right)\end{array}$ & $\begin{array}{l}p \text {-value } \\
\text { (M vs F) }\end{array}$ \\
\hline \multirow[t]{2}{*}{ Neonates } & 11.6 & & 11.30 & & 33.80 & & 86.91 & & 383 & \\
\hline & (3.9-25.8) & & $(7.60-14.30)$ & & $(22.0-44.4)$ & & $(63.9-111.5)$ & & $(106-842)$ & \\
\hline \multirow[t]{2}{*}{ Female } & 11.8 & & 11.20 & & 33.70 & & 88.3 & & 385 & \\
\hline & (3.9-25.8) & 0.350 & $(8.80-12.90)$ & 0.337 & $(28.10-38.40)$ & 0.177 & $(63.9-100.2)$ & 0.250 & $(108-842)$ & 0.813 \\
\hline \multirow[t]{2}{*}{ Male } & 11.5 & & 11.70 & & 34.80 & & 84.1 & & 355 & \\
\hline & $(7.0-25.21)$ & & $(7.60-14.30)$ & & $(22.0-44.4)$ & & $(64.2-111.5)$ & & $(106-612)$ & \\
\hline \multirow[t]{2}{*}{ I-6 months } & 9.4 & & 11.45 & & 34.70 & & 77.05 & & 346 & \\
\hline & $(2.7-17.4)$ & & $(7.40-13.40)$ & & $(24.50-40.80)$ & & (53.6-98.3) & & $(102-684)$ & \\
\hline \multirow[t]{2}{*}{ Female } & 9.5 & & 11.55 & & 35.10 & & 81.85 & & 340 & \\
\hline & $(2.7-17.4)$ & 0.232 & $(7.40-13.40)$ & 0.127 & $(24.5-40.80)$ & 0.193 & $(66.3-98.3)$ & $<0.001$ & $(102-607)$ & 0.419 \\
\hline \multirow[t]{2}{*}{ Male } & 9.0 & & 10.65 & & 33.05 & & 69.3 & & 365 & \\
\hline & $(6.2-17.4)$ & & $(8.10-13.30)$ & & $(26.0-39.60)$ & & $(53.6-78.8)$ & & $(105-684)$ & \\
\hline \multirow[t]{2}{*}{$7-12$ months } & 10.65 & & 11.40 & & 34.70 & & 67.45 & & 312 & \\
\hline & $(3.1-25.1)$ & & $(8.40-13.90)$ & & $(26.40-40.80)$ & & $(47.6-84.1)$ & & $(106-518)$ & \\
\hline \multirow[t]{2}{*}{ Female } & 10.4 & & 11.20 & & 34.10 & & 66.6 & & 323 & \\
\hline & $(6.7-19.6)$ & 0.2336 & $(8.40-13.30)$ & 0.286 & $(26.4-40.80)$ & 0.464 & $(49.2-83.0)$ & 0.145 & $(106-479)$ & 0.822 \\
\hline
\end{tabular}


Table 2 (Continued)

\begin{tabular}{|c|c|c|c|c|c|c|c|c|c|c|}
\hline Age Group & $\begin{array}{l}\text { WBC } \\
\left(10^{9} / L\right)\end{array}$ & $\begin{array}{l}\text { P-value } \\
\text { (M vs F) }\end{array}$ & $\mathrm{Hb}(\mathrm{g} / \mathrm{dL})$ & $\begin{array}{l}p \text {-value } \\
\text { (M vs F) }\end{array}$ & Hct (\%) & $\begin{array}{l}\text {-value } \\
\text { (M vs F) }\end{array}$ & $\begin{array}{l}\text { MCV } \\
\text { (fL) }\end{array}$ & $\begin{array}{l}P \text {-value } \\
\text { (M vs F) }\end{array}$ & $\begin{array}{l}\text { Platelet } \\
\text { Count }\left(10^{9} / \mathrm{L}\right)\end{array}$ & $\begin{array}{l}\text { p-value } \\
\text { (M vs F) }\end{array}$ \\
\hline \multirow[t]{2}{*}{ Male } & 11.2 & & 11.50 & & 34.70 & & 67.8 & & 298 & \\
\hline & $(3.1-25.1)$ & & $(9.30-13.90)$ & & $(27.8-40.70)$ & & $(47.6-84.1)$ & & $(\mid 25-518)$ & \\
\hline \multirow{2}{*}{ 13-18 months } & 10.45 & & 12.15 & & 36.20 & & 65.0 & & 307 & \\
\hline & $(5.5-25.10)$ & & $(9.70-13.70)$ & & $(26.30-40.70)$ & & $(52.7-78.2)$ & & $(101-564)$ & \\
\hline \multirow[t]{2}{*}{ Female } & 10.1 & & 12.20 & & 36.3 & & 65.3 & & 306 & \\
\hline & $(7.4-15.7)$ & 0.258 & $(9.70-13.70)$ & 0.121 & $(26.3-40.70)$ & 0.265 & $(57.6-76.1)$ & 0.177 & $(153-5 \mid 7)$ & 0.990 \\
\hline \multirow[t]{2}{*}{ Male } & 11.2 & & 11.80 & & 36.0 & & 63.6 & & 308 & \\
\hline & $(5.5-25.1)$ & & $(10.0-13.10)$ & & $(29.7-39.8)$ & & $(52.7-78.2)$ & & $(101-564)$ & \\
\hline \multirow[t]{2}{*}{ 19-24 months } & 9.2 & & 11.40 & & 34.60 & & 72.7 & & 357 & \\
\hline & $(5.2-21.0)$ & & $(7.00-14.50)$ & & $(22.70-44.10)$ & & $(54.8-88.7)$ & & $(104-623)$ & \\
\hline \multirow[t]{2}{*}{ Female } & 8.75 & & 10.55 & & 32.45 & & 70.85 & & 368 & \\
\hline & $(5.2-13.9)$ & 0.234 & $(8.10-14.50)$ & 0.281 & $(27.4-44.1)$ & 0.348 & $(56.3-86.8)$ & 0.118 & $(104-623)$ & 0.898 \\
\hline \multirow[t]{2}{*}{ Male } & 9.6 & & 11.50 & & 35.0 & & 72.8 & & 337 & \\
\hline & $(5.4-21.0)$ & & $(7.0-13.60)$ & & $(22.7-40.90)$ & & $(54.8-88.7)$ & & $(13 \mid-623)$ & \\
\hline \multirow[t]{2}{*}{$>2-3$ years } & 8.25 & & 10.25 & & 31.65 & & 76.4 & & 378 & \\
\hline & $(4.3-16.5)$ & & $(7.40-13.40)$ & & $(21.50-39.10)$ & & $(54.5-92.0)$ & & $(105-988)$ & \\
\hline \multirow[t]{2}{*}{ Female } & 7.95 & & 10.25 & & 31.90 & & 76.4 & & 437 & \\
\hline & $(6.6-12.5)$ & 0.145 & $(7.80-13.00)$ & 0.616 & $(22.7-38.60)$ & 0.484 & $(54.5-85.3)$ & 0.283 & $(105-988)$ & 0.158 \\
\hline \multirow[t]{2}{*}{ Male } & 8.8 & & 10.20 & & 31.25 & & 76.45 & & 361 & \\
\hline & $(4.3-16.5)$ & & $(7.40-13.40)$ & & $(21.50-39.10)$ & & $(62.0-92.0)$ & & (II2-755) & \\
\hline \multirow[t]{2}{*}{$>3-5$ years } & 7.9 & & 10.00 & & 31.10 & & 77.9 & & 447 & \\
\hline & $(4.6-12.9)$ & & $(6.60-12.90)$ & & $(23.60-38.80)$ & & $(62.4-90.7)$ & & $(100-915)$ & \\
\hline \multirow[t]{2}{*}{ Female } & 8.05 & & 10.05 & & 31.2 & & 77.35 & & 478 & \\
\hline & $(4.7-11.7)$ & 0.400 & $(4.60-12.60)$ & 0.581 & $(15.40-38.80)$ & 0.655 & $(62.4-89.4)$ & 0.222 & $(100-915)$ & 0.424 \\
\hline \multirow[t]{2}{*}{ Male } & 7.6 & & 10.00 & & 31.10 & & 77.9 & & 376 & \\
\hline & $(4.6-12.9)$ & & $(6.70-12.90)$ & & $(236-38.20)$ & & $(63.5-90.7)$ & & $(110-755)$ & \\
\hline \multirow[t]{2}{*}{$>5-10$ years } & 6.45 & & 11.70 & & 36.40 & & 80.3 & & 288 & \\
\hline & $(3.3-14.7)$ & & $(7.50-15.90)$ & & $(21.90-50.40)$ & & $(67.3-98.1)$ & & (103-719) & \\
\hline \multirow[t]{2}{*}{ Female } & 6.6 & & 10.40 & & 32.55 & & 78.9 & & 402 & \\
\hline & $(4.1-14.1)$ & 0.192 & $(7.50-15.90)$ & $<0.0001$ & $(\mid 3.0-48.9)$ & $<0.0001$ & $(67.3-98.1)$ & 0.249 & $(103-719)$ & 0.0001 \\
\hline Male & 6.3 & & 13.05 & & 42.50 & & 81.0 & & 238 & \\
\hline & $(3.3-14.7)$ & & $(10.0-15.60)$ & & $(32.5-50.4)$ & & $(68.1-88.6)$ & & $(104-388)$ & \\
\hline$>10-15$ years & 5.7 & & 13.60 & & 41.90 & & 81.4 & & 249 & \\
\hline & $(3.3-9.7)$ & & $(7.30-17.60)$ & & $(22.60-55.10)$ & & $(64.6-91.5)$ & & $(108-428)$ & \\
\hline Female & 5.7 & & 13.15 & & 41.50 & & 82.25 & & 226 & \\
\hline & $(3.5-9.7)$ & 0.401 & $(7.30-17.60)$ & 0.153 & $(22.6-55.10)$ & 0.581 & $(64.6-91.5)$ & 0.263 & $(|08-4| 3)$ & 0.185 \\
\hline Male & 5.6 & & 14.10 & & 42.70 & & 80.4 & & 263 & \\
\hline & $(3.3-9.2)$ & & $(12.10-15.70)$ & & $(35.4-47.4)$ & & $(66.5-86.5)$ & & $(156-428)$ & \\
\hline$>15-20$ years & 5.1 & & 4.40 & & 43.80 & & 85.5 & & 249 & \\
\hline & $(3.0-13.8)$ & & $(8.00-17.60)$ & & $(26.50-54.80)$ & & $(65.5-96.0)$ & & $(102-452)$ & \\
\hline Female & 5.85 & & 14.70 & & 44.8 & & 86.25 & & 238 & \\
\hline & $(3.6-13.8)$ & 0.015 & $(11.80-16.90)$ & 0.066 & $(34.7-51.9)$ & 0.086 & $(65.5-96)$ & 0.328 & $(137-452)$ & 0.523 \\
\hline Male & 4.7 & & 14.10 & & 42.2 & & 84.7 & & 262 & \\
\hline & $(3.0-8.9)$ & & $(8.0-17.60)$ & & $(26.5-54.8)$ & & (72.3-93.4) & & $(102-400)$ & \\
\hline$>20-60$ years & 5.4 & & 12.80 & & 39.40 & & 87.1 & & 214 & \\
\hline & $(3.4-12.6)$ & & $(7.40-16.40)$ & & $(25.60-52.70)$ & & $(54.0-102)$ & & $(100-402)$ & \\
\hline Female & 5.1 & & 12.60 & & 38.0 & & 84.6 & & 205 & \\
\hline & $(3.6-12.6)$ & 0.464 & $(7.40-16.20)$ & 0.205 & $(25.6-49.2)$ & 0.145 & $(57.2-98.7)$ & 0.105 & (I 10-379) & 0.160 \\
\hline Male & 5.5 & & 13.0 & & 39.7 & & 89.6 & & 238 & \\
\hline & $(3.4-8.9)$ & & $(9.50-16.40)$ & & $(29.3-52.7)$ & & $(54.0-102)$ & & $(100-402)$ & \\
\hline$>60$ years & 5.6 & & 13.50 & & 40.00 & & 89.3 & & 234 & \\
\hline & $(3.3-12.5)$ & & $(8.30-18.00)$ & & $(26.70-59.30)$ & & $(58.9-1 \mid 1.0)$ & & $(100-585)$ & \\
\hline Female & 5.8 & & 13.50 & & 40.0 & & 89.3 & & 229 & \\
\hline & $(3.3-12.5)$ & 0.215 & $(8.30-17.90)$ & 0.440 & $(26.7-56.5 \mathrm{I})$ & $0.64 I$ & $(72.9-111.0)$ & 0.386 & $(100-443)$ & 0.235 \\
\hline Male & 5.5 & & 13.45 & & 39.9 & & 89.45 & & 253 & \\
\hline & $(4.1-7.5)$ & & $(9.70-18.0)$ & & $(30.1-59.30)$ & & $(58.9-103.3)$ & & $(102-585)$ & \\
\hline
\end{tabular}

Note: Bolded data represents the p-values that were equal to or less than 0.05 indicating a significant difference of the medians of the specific parameter between male and female participants of the specified age range.

Abbreviations: WBC, white blood cell; Hb, hemoglobin; Hct, hematocrit; mcv, mean corpuscular volume; M, male; F, female. 


\section{Results}

\section{Participants}

In total, we screened 723 healthy Malawians of different ages. Sixty-three were eliminated from the study either because they were HIV infected, severely malnourished, had malaria or were asymptomatically infected with P.falciparum, or were febrile, or found have any other infectious disease (Figure 1). The remaining 660 ( 316 males and 344 females) were divided into 12 different age groups for statistical analysis (Table 1). The median age and range values for each age group are provided in Table 1. For study participants aged $>60$ years, the overall median age for both men and women was 66 years, the median age for female participants was 66 with a range of 60-81 years, and the median age for men was 70.5 years with a range of 61-92 years. Leukocyte and lymphocyte subset data of these study participants have been reported before. ${ }^{5,15}$

\section{Variation in hematological indices with age}

Median WBC counts were high in neonates $\left(11.6 \times 10^{9}\right.$ cells/L) through to 18 months of age (Table 2; Figure 2A). These then decreased in children aged between 19 and 24 months and further decreased with age, plateauing among children aged $10-15$ years at adult levels. Females aged 15 to $<20$ years had significantly $(p=0.015)$ higher WBC counts $\left(5.9 \times 10^{9}\right.$ cells $\left./ \mathrm{L}\right)$ compared with male participants
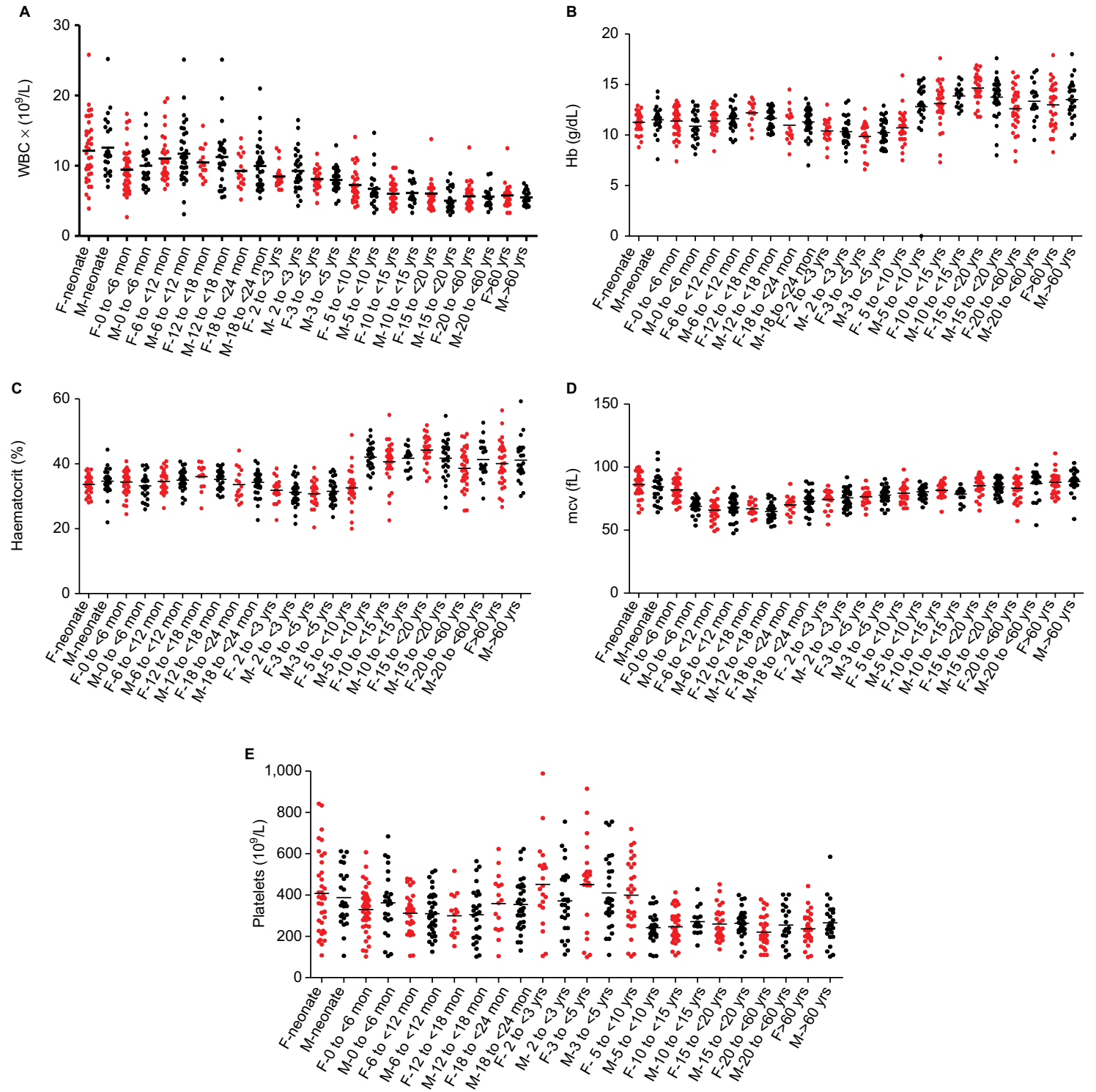

Figure 2 Median (10th and 90th percentiles) of (A) WBC counts (10\%/L), (B) Hb levels (g/dL), (C) Hct levels (\%), (D) mcv (fL), and (E) platelet counts (I0\%/L) for female (red) and male (black) study participants of different age groups.

Abbreviations: F, female; M, male; WBC, white blood cells; Hb, hemoglobin; Hct, hematocrit; mcv, mean corpuscular volume. 
$\left(4.7 \times 10^{9}\right.$ cells $\left./ \mathrm{L}\right)$ of the same age (Table 2$)$, an observation that has been noted before ${ }^{16}$ and attributed to hormonal changes in women. ${ }^{17}$

Median $\mathrm{Hb}$ concentrations were low in neonates and young children (Figure 2B). These increased among males at 5-10 years and then among females at 15-20 years to reach the highest levels (median $14.40 \mathrm{~g} / \mathrm{dL}$ ) at 15-20 years (Table 2). Median Hct followed a near identical trend to $\mathrm{Hb}$ (Figure 2C). Male participants in the 5-10 years age group had significantly ( $p<0.0001$ for both parameters) higher $\mathrm{Hb}$ $(13.1 \mathrm{~g} / \mathrm{dL})$ and Hct $(42.5 \%)$ compared with females of the same age (10.4 g/dL and $32.6 \%$, respectively).

Median mcv peaked in neonates ( $87 \mathrm{fL})$, decreasing gradually with age to a nadir of $67.8 \mathrm{fL}$ among children aged 13-18 months (Figure 2D). This was followed by a gradual increase reaching a peak of $89 \mathrm{fL}$ in adults $>60$ years. Female babies in the $1-6$ months age group had significantly $(p<0.0001)$ higher mcv values $(81.85 \mathrm{fL})$ compared with male babies in the same age group (69.3 fL) (Table 2).

Median platelet counts peaked in the 3 to $<5$ years group for both girls $\left(478 \times 10^{9} / \mathrm{L}\right)$ and boys $\left(376 \times 10^{9} / \mathrm{L}\right)$ (Table 2 ; Figure $2 \mathrm{E}$ ). This was a followed by a gradual decrease with the lowest counts $\left(205 \times 10^{9} / \mathrm{L}\right.$ for females and $238 \times 10^{9} / \mathrm{L}$ for males) observed in the 20 to $<60$ years aged group (Table 2 ). Females aged 6-10 years had significantly $(p=0.0001)$ higher platelet counts compared with males $\left(238 \times 10^{9} / \mathrm{L}\right)$ of the same age group (Table 2).

\section{Discussion}

We have reported values for $\mathrm{WBC}$ count, $\mathrm{Hb}, \mathrm{Hct}$, mcv, and platelet count for healthy Malawians residing in a township in Blantyre from birth to adults in their nineties. Male and female adults have lower values for WBC, $\mathrm{Hb}, \mathrm{Hct}$, mcv, and platelet counts compared to published standard values for Caucasian populations. ${ }^{18}$ In one age group in the current study (5-10 years), females had lower $\mathrm{Hb}$ and Hct values than males. Previous reports from Malawi only provided ranges for healthy children aged between 0 and 6 months, ${ }^{12}$ in neonates, ${ }^{13}$ and in adults aged between 19 and 30 years. ${ }^{14}$ The values from the present study fell within the ranges established for the previous study but provided more finesse and detail with respect to age and sex. In both studies, healthy study participants had hematological values outside reference ranges for Caucasian populations. In the absence of ranges established among Malawian subjects, such results could be misinterpreted as indicating an underlying medical problem.

Similar to studies conducted among western populations, ${ }^{19,20}$ and other African populations, ${ }^{3,8} \mathrm{Hb}$ and Hct levels in Malawian children were comparable regardless of sex from birth to 10 years. The age groups between 5 and 10 years for boys and 10 and 15 years for girls mark a transition from childhood to adulthood values, with $\mathrm{Hct}$ and $\mathrm{Hb}$ higher in the older age groups. Few publications have reported $\mathrm{Hb}$ variation with age to adulthood. One study, in an Indian population from the age of $12-90$ years, ${ }^{21}$ and another one among British, American, and Canadian Caucasian subjects from birth to adulthood ${ }^{22}$ observed that male participants had higher $\mathrm{Hb}$ values compared with female participants from 12 years onward. Overall, the $\mathrm{Hb}$ results obtained in our study are lower compared with those in the western adult population, ${ }^{22}$ but higher than those of the Indian study, ${ }^{21}$ and this might be attributed to a lower than normal dietary iron intake that could impair hematopoiesis. ${ }^{7}$ The finding could also be due to chronic erythrocyte loss due to intermittent malaria or hookworm infestation, both of which are common in the region. ${ }^{6}$

The difference observed in the age groups in which platelet counts drastically decreased, between 3 and 5 years in males and 10 and 15 years in females, could be due to estrogen in females which has been associated with changes in platelet function. ${ }^{23}$ The lower platelet counts observed in the Malawian population compared to the standard reference ranges $^{12}$ might be the result of environmental or genetic factors or both. ${ }^{17}$ However, the observation that even among African populations ${ }^{2-6}$ these counts vary substantially suggests that environmental factors are important. Other studies have reported that adult females have higher ${ }^{2,7-9,17}$ or similar $^{5,23}$ platelet counts compared with adult males.

When compared to standard reference ranges, ${ }^{18}$ which are set for Caucasians aged between 20 and 60 years, Malawians had lower values for $\mathrm{Hb}$, Hct, and platelet counts. When compared to values for other African subjects, Malawian male participants had lower $\mathrm{Hb}$ and Hct values than those in male participants from Uganda, ${ }^{8}$ Central African Republic, ${ }^{3}$ Botswana, ${ }^{6}$ Tanzania, ${ }^{9}$ and Kenya, ${ }^{10}$ consistent with the importance for environmental factors in determining such intercountry differences.

When the normal reference limits of the Beckman Coulter hematological analyzer, which were obtained after analyzing blood samples from healthy Malawian controls, ${ }^{14}$ were taken into consideration $\left(2.8-7.2 \times 10^{9} / \mathrm{L}\right.$ for WBC counts, 13.6-16.7 $\mathrm{g} / \mathrm{dL}$ for $\mathrm{Hb}, 39.0 \%-50.0 \%$ for Hct, 82.0-98.0 fL for mcv, and $115-290 \times 10^{9} / \mathrm{L}$ for platelets), results for all parameters analyzed in all age groups were within those set limits.

The results of this study complement findings from a previous Malawian study ${ }^{14}$ which found age and sex variations 
of hematological values in participants aged between 19 and 35 years. Considering various studies that have reported a variation of hematological parameters based on ethnicity, age, and sex, the values reported in this study provide additional information on how such values vary with age and with sex in Malawi.

\section{Limitations}

Our study had a number of limitations including variations in the numbers of male and female participants in the different age groups and lack of detailed information concerning past medical history, including recent infections. Collection of specimens was not performed at a constant time of the day and social details such as smoking were not recorded. Furthermore, all study participants were recruited from one location in Blantyre, Ndirande township, which is a peri-urban setting. Also, although we had planned to recruit equal numbers of participants for each group, we ended up with variable samples sizes for the different age groups and particularly for males and females in each group, partly through the exclusion of some participants based on the screening results included in Figure 1. Lastly, although a previous Malawian study ${ }^{14}$ had suggested the need for collecting data on key behavioral, dietary, and environmental factors that might affect hematological variables, our study only excluded severely malnourished subjects.

Ndirande is a large township with $>109,164$ inhabitants $^{24}$ of different Malawian ethnic backgrounds including Chewa, Nyanja, and Ngoni from the central region, Yao, Mang'anja, and Sena from the southern region, and Tumbuka and Nkhonde from the northern region, who have over the years migrated to the city. ${ }^{25}$ With such a diversity in the ethnic background of the study population, it is not easy to ascertain that the variations observed in hematological values from other studies are purely due to age or sex alone. Any future study aiming to establish reference hematological ranges representative of the ethnic tribes in Malawi will need to recruit participants of known ethnicity. If values from the same participants are collected at least at two time points, during the dry season and the wet season, the average of the two values would help eliminate seasonality as a potential confounder.

\section{Conclusion}

In conclusion, we have shown, as others have, that hematological parameters vary with age and with sex. When compared with results of other studies, there are regional and ethnic differences in reference values of hematological indices between African and Caucasian populations as we have previously described for leukocyte and lymphocyte subsets. ${ }^{5}$ Even among African populations, these values vary supporting the concept that each country should establish its own set of normal hematological reference ranges. These should be performed in carefully characterized healthy participants representative of all ages and both sexes, and should ideally be representative of all ethnic groups in that country.

\section{Acknowledgments}

We thank the two research nurses, Grace Mwimaniwa and Meraby Mfunsani, and the clinical officer, Paul Pensulo, for collecting blood samples from the participants, Felanji Simukonda for performing the FBCs, and all individuals who participated in this study. This work was supported by a PhD studentship from the Gates Malaria Partnership (to WLM) which received support from the Bill and Melinda Gates Foundation, a Wellcome Trust Research Fellowship (to CAM), a Wellcome Trust Programme Grant (to MEM), and a Clinical Research Fellowship from GlaxoSmithKline (to CAM).

\section{Author contributions}

WLM, JM and CAM conceived the study. WLM, JM and EG performed the investigations. All authors contributed towards data analysis, drafting and critically revising the paper and agree to be accountable for all aspects of the work.

\section{Disclosure}

The authors report no conflicts of interest in this work.

\section{References}

1. Tsegaye A, Messele T, Tilahun T, et al. Immunohematological reference ranges for adult Ethiopians. Clin Diagn Lab Immunol. 1999;6:410-414.

2. Mahlknecht U, Kaiser S. Age-related changes in peripheral blood counts in humans. Exp Ther Med. 2010;1(6):1019-1025.

3. Menard D, Mandeng MJ, Tothy MB, Kelembho EK, Gresenguet G, Talarmin A. Immunohematological reference ranges for adults from the Central African Republic. Clin Diagn Lab Immunol. 2003;10:443-445.

4. Uppal SS, Verma S, Dhot PS. Normal values of CD4 and CD8 lymphocyte subsets in healthy Indian adults and the effects of sex, age, ethnicity, and smoking. Cytometry B Clin Cytom. 2003;52:32-36.

5. Mandala WL, Ananworanich J, Apornpong T, et al. Control lymphocyte subsets: can one country's values serve for another's? J Allergy Clin Immunol. 2014;134(3):759-761.

6. Mine M, Moyo S, Stevens P, et al. Immunohaematological reference values for HIV-negative healthy adults in Botswana. Afr J Lab Med. 2012;1(1):5

7. Al Qouzi A, Al Salamah A, Al Rasheed R, et al. Immunophenotyping of peripheral blood lymphocytes in Saudi men. Clin Diagn Lab Immunol. 2002;9:279-281.

8. Lugada ES, Mermin J, Kaharuza F, et al. Population-based hematologic and immunologic reference values for a healthy Ugandan population. Clin Diagn Lab Immunol. 2004;11:29-34. 
9. Buchanan AM, Muro FJ, Gratz J, et al. Establishment of haematological and immunological reference values for healthy Tanzanian children in Kilimanjaro region. Trop Med Int Health. 2010;15(9):1011-1021.

10. Zeh C, Amornkul PN, Inzaule S, et al. Population-based biochemistry, immunologic and hematological reference values for adolescents and young adults in a rural population in Western Kenya. PLoS One. 2011;6(6):e21040

11. Kueviakoe IM, Segbena AY, Jouault H, Vovor A, Imbert M. Hematological reference values for healthy adults in Togo. ISRN Hematol. 2011;2011:736062.

12. Kumwenda NI, Khonje T, Mipando L, et al. Distribution of haematological and chemical pathology values among infants in Malawi and Uganda. Paediatr Int Child Health. 2012;32(4):213-227.

13. Mukiibi JM, Mtimavalye LA, Broadhead R, et al. Some haematological parameters in Malawian neonates. East Afr Med J. 1995;72(1):10-14.

14. Chisale MR, Kumwenda P, Ngwira M, M'baya B, Chosamata BI, Mwapasa V. A pilot study to determine the normal haematological indices for young Malawian adults in Blantyre, Malawi. Malawi Med J. 2015;27(3):96-100.

15. Mandala WL, MacLennan JM, Gondwe EN, Ward SA, Molyneux ME, MacLennan CA. Lymphocyte subsets in healthy Malawians: implications for immunologic assessment of HIV infection in Africa. J Allergy Clin Immunol. 2010;125:203-208.

16. Bain BJ. Ethnic and sex differences in the total and differential white cell count and platelet count. J Clin Pathol. 1996;49(8):664-666.
17. Santimone I, Di Castelnuovo A, De Curtis A, et al. White blood cell count, sex and age are major determinants of heterogeneity of platelet indices in an adult general population: results from the MOLI-SANI project. Haematologica. 2011;96:1180-1188.

18. Wintrobe MM, Lee GR. Wintrobe's Clinical Haematology. 10th ed. Baltimore, MD: Lippincott Williams \& Wilkins; 1999.

19. Flegar-Mestric Z, Nazor A, Jagarinec N. Reference intervals for haematological parameters in urban school children and adolescents. Clin Lab Haematol. 1999;21:72-74.

20. Taylor MR, Holland CV, Spencer R, Jackson JF, O'Connor GI, O'Donnell JR. Haematological reference ranges for school children. Clin Lab Haematol. 1997;19:1-15.

21. Yandamuri A, Yandamuri N. Survey on haemoglobin level in the different age groups of male and female human beings living in the rural and urban area. Int J Pharm Sci. 2013;5(2):2086.

22. Hawkins WW, Speck E, Leonard VG. Variation of the hemoglobin level with age and sex. Blood. 1954;9:999-1007.

23. Cowman J, Dunne E, Oglesby I, et al. Age-related changes in platelet function are more profound in women than in men. Sci Rep. 2015;5:12235.

24. Kazembe LN, Mathanga DP. Estimating risk factors of urban malaria in Blantyre, Malawi: a spatial regression analysis. Biomedicine. 2016;6(5): 376-381.

25. Bettison DG, Apthorpe RJ. Authority and residence in a peri-urban social structure - Ndirande, Nyasaland. Nyasaland J. 1961;14(1):7-40.
Journal of Blood Medicine

\section{Publish your work in this journal}

The Journal of Blood Medicine is an international, peer-reviewed, open access, online journal publishing laboratory, experimental and clinical aspects of all aspect pertaining to blood based medicine including but not limited to: Transfusion Medicine; Blood collection, Donor issues, Transmittable diseases, and Blood banking logistics; Immunohematology; Artificial and alternative
Dovepress

blood based therapeutics; Hematology; Biotechnology/nanotechnology of blood related medicine; Legal aspects of blood medicine; Historical perspectives. The manuscript management system is completely online and includes a very quick and fair peer-review system. Visit http://www.dovepress.com/ testimonials.php to read real quotes from published authors. 